\title{
Communication, Socialization and Citizenship: Theoretical-Conceptual Bases to Understand the Expression of Contemporary Citizen Politics
}

\author{
Vivian Romeu ${ }^{1}$, Maylen Alvarez ${ }^{2}$ \\ ${ }^{1}$ Dra. Vivian Romeu, Universidad Iberoamericana, Communication Department, Mexico \\ ${ }^{2}$ Dra. Maylen Alvarez, Universidad Iberoamericana, Mexico \\ Correspondence: Vivian Romeu, Dra. Vivian Romeu, Universidad Iberoamericana, Communication Department, \\ Mexico.
}

Received: May 15, 2019

doi:10.11114/smc.v7i2.4428

\author{
Accepted: July 31, 2019 \\ Online Published: August 6, 2019 \\ URL: https://doi.org/10.11114/smc.v7i2.4428
}

\begin{abstract}
This text reflects theoretically and conceptually on the contemporary political expression of citizenship - which we have also named as emergent, given its recent appearance and its novel forms and contents - from three perspectives of analysis: that of science and political philosophy, from the approach of inclusive citizenship around the binomial citizenship-rights; that of relational sociology that makes it possible to think of citizen's political action practices as practices of individual-individual relationship; and communication as an expression, from which political expression is conceptualized as a communicative phenomenon and its levels of analysis are delineated. The result implies recognizing these practices as a possible revitalization/re-foundation of democracy, under the guarantor of human rights.
\end{abstract}

Keywords: communication, political expression, human rights, citizenship, sociability

\section{Introduction}

The long road of Modernity and its postmodern wear has ended up encouraging strong questions about its democratic maxim. The myth of representation and equality, at least in our country, has become increasingly evident, although the phenomenon certainly seems to be global. This has placed in the citizen political imaginary an imprint that leads to the perception of a static political institutionality and trapped in the institutional mechanisms of democracy itself, where it is no longer possible to assert the right to citizen vote as a right of political representativeness.

In response to this, the scenarios of citizen political participation have expanded, triggering citizenship processes that are likely to be thought of as new forms of civic empowerment in which the sphere of the public is embedded in the political sphere by setting options from which citizens demand to be recognized as subjects of rights.

This is crossed by the democratizing processes that are freed at the time of the hand of globalization, and specifically by the mood of freedom, transparency and rights that this entails (Reguillo, 2003), especially since the emergence of digital social networks, where the State is constantly questioned by the pressure of citizens.

In that sense, today we are witnessing the emergence of a stronger and more politically aware citizenship of their weight in the political arena, although this is far from being a homogeneous phenomenon. However, citizen political participation is there and is expressed through new forms and content that, we believe, are closely linked to the globalist guarantee narrative that is gradually entering into the feeling, thinking and collective action. This in turn results in diversified processes of citizen political participation in the public sphere that oscillate between the already known social movements and the requirement of recognition of the political subject beyond the institutional instances of politics in their State-individual relationship and even State-civil society, to settle on the grounds of a relationship of individual-individual, citizen-citizen horizontality, the consequences of which still await thought and evaluation (Jonhson, Botswick \& Cionea, 2019; Meeks, 2016a; Mierick \& Dunn, 2015 ; Reedy, 2015).

Precisely around this last topic, the text presented here is organized, trying to answer the question how can we study from an analytical perspective of communication, this emerging, alternative citizenship, around the requirement of individual recognition as a subject of rights to guarantee their legitimate enjoyment?

As the reader will appreciate, it is a text of a theoretical-conceptual nature that seeks to explore the theoretical bases that allow apprehending this emerging phenomenon that has been activated recently in our country and in the world. 
Apparently, these phenomena find sense in the displacement and dwarfing of the political function of the neoliberal state in order to found a new order of the political from the public. On the other hand, the nature of our guiding question will also allow us to understand from what theoretical and epistemic place it is possible to specify the study of these citizen practices, from the field of communication studies. We will structure this exhibition in three parts. The first of these will address the difference between the concepts of politics and politics, as well as the different meanings acquired by the concept of citizenship under it. This will serve as a basis for incorporating a reflection on what we have called new forms and contents of citizen political participation today, based on the postulates of liberal political philosophy focused on citizen rights. A second section will attempt to specify a conceptualization of these phenomena as eminently communicative phenomena, thus setting a path for their study from the field of communication studies. In this part, it is intended to articulate a reflection on the communicative from the concept of political expression, indicating the levels of analysis of it. With this we will also give way to a methodological outline of its possible approach. Finally, in the third section, it is intended to convey a more complete reflection on the above from the conceptual frameworks of sociology, with the aim of offering a reflection that leads to think about the new forms and contents acquired by emerging political practices in our contemporary societies from the field of social relations and their possible consequences.

\section{Emerging Citizen Political Participation: Theoretical Concepts and Approaches}

The guaranteeing turn taken by the study of citizenship and non-electoral political participation requires reviewing a series of concepts and theories linked to citizen political action. Human rights shape the crux of this approach, specifically as rights under an individualistic condition of subjective legitimation, as Kabeer (2005) points out, making it possible to think about citizenship and citizenship processes in society from a different perspective, and promoting even a freer, more inclusive and equitable society; more fair in every way. This places the mechanisms of non-electoral political participation as enhancers of citizen exercise through the political empowerment of the subjects as subjects of rights.

Thus, while the policy under its institutional leadership signed by the State has long constrained the forms of political participation in the exercise of the vote, today the political has been gaining ground and visibility as an instance of citizenship. Following Canetti, according to Chantall Mouffe (1999: 14), politics is the institutional order from which human existence is governed, establishing from it forms and mechanisms to resolve the conflicts inherent in diversity, and the consequent antagonism of Social relations. On the other hand, for this same author, the political is the non-institutional order or agreement that governs diversity itself, which is marked in terms of antagonism and hostility as it emerges from the peculiarities from which every human relationship is gestated. Political and political are thus expensive of the same currency, interdependent: politics helps to regulate the political institutionally, and the political in turn nourishes politics (Reedy, Gastil and Moy, 2015; Mierick and Bessarabova, 2015). This, as you can see, makes the political, and even also of politics, a social relationship in the public sphere (Arendt, 1997), that is, a relationship between individuals, only that in politics this relationship occurs between individuals with different political hierarchy (those who govern and those who are governed), while in politics this relationship takes place from more horizontal instances that point, in essence, to the individual-individual relationship.

Díaz (2003: 50-52) summarizes the political as a collective way of managing plurality and human difference through values such as justice, equality, solidarity, etc., from a doxastic narrative. In that sense, for this author, the political are the discursive contents that are expressed in the daily political practice of individuals in the public sphere, understood through political action linked to aspects such as freedom, legitimacy, practices, identities, subjectivity, alterity, etc. In contrast, the author points out, the policy focuses on the forms of government and institutional mechanisms that govern the public, as well as on the legitimate and legal procedures that allow the organization and co-existing articulation between the diversity of interests and forms of think and live that characterizes the human condition. In today's societies, the main form of government is democracy, understood as one that has allowed plurality to be better managed, by regulating access to power more equitably. However, this has also led to the construction of an imaginary around democracy itself that has forged what many authors call the democratic lifestyle. For example, Díaz and Valencia (1998) point out that this democratic lifestyle is installed in the microsocial on a daily basis, being able to be institutionalized or not, but always articulating practices and speeches that can potentially transcend the public to settle in the private, where acquires a less normative, less tax and regulatory nature of collective living, which in turn is what creates the conditions for self-reflection, self-determination, freedom and responsibility for citizens' action. Under the aforementioned, it can be affirmed that although from democracy as a form of government, the ideals of demand and citizen participation shape its instrumental justification, it is precisely the latter that legitimizes the narration of citizen rights as human rights, set in the conception and philosophical tradition of liberalism, which is based on three fundamental principles or criteria: the inviolability of the person, his autonomy and his dignity.

The first of these principles conceptualizes a limit scenario for the State's action based on the violence that it cannot exert on the individual; the second, closely linked to the first, is based on personal freedom in terms of life plans, ideals and personal goals; but the third is related to the individual's own recognition as a subject of rights without any other attribute 
(race, ethnicity, social and cultural belonging, age, sex, level of study or professional, etc.). From this perspective, according to Díaz (2003: 54), democracy becomes an instance for the deployment and promotion of individual freedom, from a civic dimension that emphasizes the very sense of citizenship from a realization level that guarantee the exercise of civility.

In accordance with this we can say that civility promotes a cultural ethos strongly associated with human rights as a discursive and practical regime where political, legal and ethical coexistence converge (or should), and it is also possible to say in this regard that this civility promotes, from an ethical-social dimension, a collective citizen identity, created both from the public space and from the private space.

Notwithstanding the foregoing, there is a necessary condition for this level of realization of democratic civility to find an effective cause for its deployment. We refer specifically that democracy must rebuild its lost link of origin; or put another way: it must cease to be only a discourse to become action, exercise.

In our view, it is precisely this link of origin, associated with the aforementioned principles of civility, that has been broken in the present times. The democratic exercise of politics has demonstrated the myths and contradictions of democracy itself. The myth of representativeness, for example, closely associated with the principle of majority - except in parliamentary political regimes, which works somewhat better than in presidentialists - representativeness is divided into partisan fractions, which nevertheless leave out those who do not access to power in that way, questioning her. The same applies to the majority principle - better than any other so far - but certainly also a myth of democracy that must be reviewed, adjusted, because most do not represent the total, but only a part of it, and here, again, the fence is narrowed with respect to the myth of representativeness. As if that were not enough, in today's politics the limits and counterweights of the rulers have also been broken, corruption is rampant - especially in our hurting Latin American societies - social injustice leaves much to be desired of a democratic system that has in charge of being it rather in electoral terms, but that has not managed to impact as a system on the life of our societies, thereby immobilizing the very sense of citizenship in politics. Given this crossroads, and based on an "informal" political participation that is expressed mainly in digital social networks (Meeks, 2016b), although not only, the new approaches to citizenship as a form of belonging and capacity for action "from below"(Kabeer, 2005), allow us to think of the emergence of a citizenry capable of articulating from social relationships and the recognition of others as subjects of rights, that is, as legitimate rights holders. We experienced it during the events of September 19, 2017 in Mexico, when citizens moved not only to help the victims, but also to inform themselves.

The approach of citizenship "from below" emphasizes this social relationship between citizens, much more horizontal than citizenship as we know it. However, it should not be thought that this relationship is relegated from the citizen-State relationship, but rather that the relationship between citizens points in the same direction as that, with the addition that this citizen participation is much more plural and heterodox, while it is given through areas of political participation, apart from, potentially, electoral participation, which is where the study of citizenship is mostly focused today. Thus, the exercise of citizenship "from below" is achieved through the implementation, also "from below," of individual and citizen rights, although this is only possible if the citizens in question have knowledge of their own rights, both formally and informally. This configures new ways of participating in the public sphere; for example, from this perspective, the formation of citizens and the effective exercise of this condition, has ceased to be thought only from the areas of politics to be assumed as part of a process of socialization and participation in the public focused on the extension of new types of rights, in the manner of processes and mechanisms of subjective legitimization that empower citizens politically.

In this regard, Kabeer (2005) argues that, from the perspective of inclusive citizenship - which is another way of naming this conceptual figure of citizenship "from below" -, the question about the meanings and practices carried out by marginalized subjects in An unequal society configures another type of citizenship more linked to practice than to regulations, as opposed to the aspect of citizenship that has been traditionally conceptualized from political science. This is in line with what Blanco and Díaz (2005) suggest that conscience and the struggle for individual recognition as a subject of rights and for their legitimate belonging to the social space, could contribute in different degrees to the activation and / or deployment of citizen action in terms of both social welfare and quality of life, in accordance with the affective and political integration of the social environment to which it belongs, and thus aiming at the protection of individual rights as rights for the free development of personality.

Reaching this emerging conceptualization of citizenship has meant going through a series of reflections that are still in dispute from science and political philosophy. The pioneer on the subject, Thomas Marshall (1998), defines citizenship as a right of belonging to a political community that is sustained through three types of rights: civil, political and social rights. From this author's perspective, civil rights are those that include procedural guarantees and the right to nationality or belonging; political rights have to do with the possibility of representing and being represented, and what is related to the vote; and finally, although not necessarily in that order, social rights are related to the right to social security and the 
minimum guarantee of welfare in a society, as rights that must be guaranteed by the national State.

As you can see, from Marshall's position, citizenship has as problematic axes both the problem of rights and the problem of justice since both are conceived from an institutional normative point of view, that is, in terms of rights and procedures which are guaranteed by state institutions mainly. In that sense, for this author, citizenship has to do with communitarianism that translates into the question of belonging to, and the identity of a political community, in terms of dealing with the resolution of what it means to be a citizen of a place and belong to it. Trying to close the gap between citizen rights guaranteed by the State and the conceptualization and exercise of other rights that have emerged from the complexity of contemporary societies, another position that also addresses the concept of citizenship is summarized in the multiculturalism approach, whose main representative is Will Kymlicka. This author adds to the Marshall proposal a fourth right that has to do with the right to diversity, but this approach is developed from a different frame of reference to Marshall's since it takes into account when talking about citizenship to populations individuals or individuals, as well as civil individuals. And it is that the Kymlicka rights system, although compatible with that of Marshall's rights, focuses rather for its guarantee in institutions such as the family, education and the market, to name a few, in addition to the state level. However, from Kymlicka's multiculturalism, it is argued that the integration of the difference presupposes that community rights must be guaranteed above the individual rights, thus placing itself next to Marshall in this regard.

Despite this, recently, from the studies on civil society, it is understood as a political-citizen alternative mediator between individuals and the State through citizen participation as a key mechanism for the scope of rights (Olvera, 2008), An analysis edge has emerged for the study of citizenship in contemporary societies. This position took force in the Social Sciences in the 90s and although from it the postulate of communitarianism understood as a citizenship of difference is taken up, the truth is that it also focuses on the debate of political participation in the public space and not necessarily electoral, as an effective way to achieve civil rights. This is the case, for example, of social movements in their relationship with the State. This approach to citizenship from the concept of civil society has had an impact on the debate about citizenship through thinking at the same time from the public sphere not necessarily linked to politics. From there, the social dimension of the political is consolidated as a legitimate instance of analysis to understand political participation in contemporaneity. It is in this context that the approach of inclusive citizenship proposed by Kabeer (2005) arises, which although it can be located in the position of multiculturalism as much as in that of civil society (in the sense that it is also a citizenship which takes up the differences, that is, the real conditions of individuals, such as race, ethnicity, education, etc.), distances themselves from these approaches since it not only recognizes political and social practices from the political in their civil society relationship- State, but also takes up the private sphere and the individual who inhabits it as an instance of demand in the recognition of their citizens' rights, making the possession of a right an intrinsic attribute of the citizen. Making the law a citizen attribute, unlike understanding it as a property or possession granted by the State, makes visible and empowers the citizen as a subject of law, beyond even their participation or belonging to a political community.

From this approach of inclusive citizenship, as you can see, citizenship is associated with cultural practices and meanings that influence their formation from a less normative vision and more focused on the practices of citizens who, unlike the position of The civil society that dialogues with the State directly through the mechanisms of informal political participation, assumes as citizens the individuals from whose daily practices of subjective legitimization and the struggle for both individual and social recognition of their rights, aspire to reach and enjoy them.

In this same epistemic line, is the work of Dagnino (2008) which studies the problem of the implementation and exercise of rights in populations where there is a great marginalization and conditions of inequality among many of its members; these in turn claim not only to be recognized as belonging to a place, and as such as subjects of political and civil rights, but, above all, demand to be recognized by other citizens (eye, no longer the State) as subjects of rights. The struggle of the LGTBI community for the recognition of their rights - some of which have even been legally recognized - reliably illustrates this.

This emerging vision of citizenship seems to be quite adapted to the way in which it is organized and articulated today. It is not in any case to ignore the scope of civil, political and social rights of citizens, nor to abort the sense of citizenship protected by civil society. What Kabeer and Dagnino are proposing seeks rather to add to all these rights, an ethical-political perspective protected by the very feasibility of the contemporary citizen exercise that is essentially based on the particular relations between individuals and which is what we have previously mentioned as emerging citizens as long as this new type of political relationship around the citizen-citizen relationship is postulated.

As you can see, it seems undeniable the impact that this new approach to citizenship could have on the development of culture, even from a civilizing perspective. The articulation between / of the citizens from the perspective of inclusive citizenship not only allows explaining the spontaneity, horizontality and circumstantiality of citizen political participation today, but also in our opinion, its dissimilar forms and areas of participation. In that sense, the heterodoxy of a conceptual 
approach like this, allows us to think about the possibility of achieving, from this citizen articulation outside the State, a greater symmetry in social relations depending on the processes and mechanisms around the recognition of citizen rights, in terms of a more inclusive citizenship.

Under these criteria, the approach of inclusive citizenship is based not only on an ethical perspective of politics and politics, but also on the liberal budgets that encourage it, especially around the core of cultural diversity, a core that also touches the Kymlicka multiculturalism. Thus, under the right to diversity all generations of rights are instituted and it is fair from this that it also considers citizen action as the participatory political action of citizens based on the exercise and enjoyment of their individual and collective rights in the Public ambit. Actions such as those of the already extinct \# YoSoy132, the controversy and the action of constitutional controversy around the legalization of the recreational use of cannabis in Mexico, citizen movements in favor of respect and recognition of sexual diversity and gender equity , practices and speeches in favor of security and against femicides, the set of citizen strategies by family victims of forced disappearance in their search, comments and increments around government actions accused of corruption or inefficiency in digital social networks, the null or flat vote does not go to vote, the legitimate claim of high school and high school students who run out of options to continue their higher level studies in Mexico, vegan initiatives and vegetarians against specism, the citizen organization in favor of the care and adoption of domestic animals, environmental movements, the professional organization of Doctors Without Borders, which are in favor of the consumption of recycled perishable products and against voracious and dilapidating consumerism, etc., all of them, among other examples, are emerging citizen political actions, new and alternatives, which are configured both collectively and individually, in response to the inaction or inefficiency of the State and from the conviction responsible for the freedom and autonomy granted by citizenship.

These citizen political actions, both individually and collectively, are likely to be conceptualized as communicative actions, that is: as emerging communicative practices within the broader landscape of actions and / or practices in political communication. The reason for the above is found in the principle that all communicative action and / or practice is essentially an action and / or practice of expression, and in the case at hand - which are contemporary citizen political practices - this can be defined equivalently as citizen political expressions.

Thus, in the same way that it has been necessary to forge a more updated definition of the concept of citizenship to apprehend conceptually and theoretically the type of phenomena that we have described as citizen action and / or practice, it is necessary, from the field of studies on the communication, review the concepts of political communication with which it has operated mostly and define them from an analysis perspective that allows them to be understood as part of the phenomena of citizen political expression today. We will address that in the next section.

\section{Communication and Citizen Political Expression. Conceptual and Methodological Bases}

As we have seen before, the citizen political expression that we have characterized as emerging is based on subjective legitimation mechanisms that are configured from the socio-cultural practices of individuals and / or social groups. This has put into consideration a concept of citizenship supported by the symmetry of expanded rights, creating a radicalization of the concept that goes from the legal guarantee of civil, social and political rights, to the very guarantee of the exercise of citizenship through the recognition of the right to difference from the beginning of diversity.

While it is true that this right to difference is implied within the set of first-generation civil rights proposed by Marshall, we must emphasize that to describe and explain the contemporary phenomena of emerging citizen political expression, from the configuration of the Inclusive citizenship, it must be borne in mind that the right to diversity is confirmed as a socio-cultural right that, depending on the free development of the subject's personality, guarantees his full exercise and enjoyment as a subject of law.

That is, we refer here to the fact that the right to diversity, also conceptualized from multiculturalism and the approach of inclusive citizenship as the right to difference, has enhanced the emergence of a much more democratic criterion that contemplates a conception of individual rights precisely involved in the particularities and preferences of individuals, regardless of their membership in a political community. It is a position that, as already said, is based on the practice of a daily life that specifically impacts the emergence of a democratic lifestyle rather than the normative status of citizenship as a subject of rights.

From this democratic lifestyle just hinted at in our current Latin American societies, it is precisely the citizenship that, with its spontaneous, circumstantial and more or less horizontal citizen exercise, cries out and struggles, sometimes without being fully aware of it, for the achievement of a more inclusive society for all, both in discourse and in everyday practice (legal or not, dominant / hegemonic or not). For this reason, from the inclusive citizenship, this right to difference basically promotes the emerging citizen political expression as the right to free expression, which in turn makes citizen political expression a citizen practice today as a lived experience , "He says", from the citizen's own practice, of the construction of a new type of citizenship that is likely to be studied through communication studies. 
Communication, and specifically political communication, has been understood so far from the implications that are held around social interaction, understanding by it the sphere from which social relations take place, and in the case of political communication relations between individual / civil society and State. This tripartite relationship passes through the media and its imprint in the formation of public opinion. It is basically about conceptions that relate to the macrosocial level of democracy, without thereby disabling the microsocial instance from which social movements are organized and studied, for example, a clear antecedent of what we have named as emerging citizen political expression. However, as already mentioned, the approach of inclusive citizenship perseveres in the conceptual treatment of emerging political expression as an instance of subjective recognition in terms of rights, which implies thinking or reviewing how this is likely to be understood from the communication.

Most of the multiple definitions that have been built on communication suggest that this is a phenomenon whose raw material is the meanings, and the meanings are mental constructions or representations that we assign to things either through the perceptual experience of individuals. and / or by the social learning of the sociocultural meanings given in advance within the social life in which they are developed. In both cases, however, through communication, these meanings are conveyed, forming what we normally know as a message.

Thus understood, a message is nothing other than the result, first, of the construction of meanings through perceptual experience and / or social learning by an individual and / or social group, which is subsequently specified through a projection of them abroad, the public sphere. This outward projection of the meanings previously constructed by the individual and / or social groups, is what we can call expression; Expression as it constitutes the vehicle of these meanings, configuring both a form and a content where they acquire external visibility, and eventually for the other citizen.

But the meanings as coming from the perceptual experience and / or social learning by individuals and / or social groups are configured as unique, depending on, in the case of the former, the vital, emotional-emotional and organic nature of the same, and in the second case due to its socio-historical character, always overlapped also from the perceptual experience located. For that reason, the communicative expression - whether that is political in nature - does not always "share" the meanings or make them interchangeable as long as they are linked to understanding. The communicative expression projects the meanings to the outside and these become understandable or not for an eventual other as long as the codes of representation of the meanings in question are shared (Romeu, 2018).

This implies understanding communication from the point of view of understanding as something circumstantial and to some extent possible, which does not prevent its concretion as a communicative expression. In the case of the emerging citizen political expression that we have been talking about, this implies understanding it as communication regardless of whether the meanings it projects or not are understood. But it is not about understanding this expression as a mechanism for the transmission of information because this concept implies the idea of a deliberate action towards the reception of the other that is not always fulfilled in the political practices of emerging citizens in contemporary times. Rather, it is about understanding that communication as an act of expression is outside the understanding, as indicated by Peters (2014).

In that sense, the mere communicative expression, that is: the mere projection of meanings, in this case political, does not guarantee or have to guarantee the understanding on the part of the other. This is an aspect that mostly underlies the current conceptualization of communication, but in reality communication is not defined ontologically from the understanding (Romeu, 2016; 2018). The so-called communicative interaction as a place of exchange of information or meanings based on understanding is also a myth because it can never be fully guaranteed in a communicative interaction. In fact, for this to happen, the sociocultural symbolic referents must be shared collectively; and since a good part of these are constructed from differentiated sociocultural positions that make society an asymmetric set of individuals in interaction, it is possible to affirm that despite the hegemonic and socially shared cultural referents, the sociocultural referents of individuals and / or individuals always emerge. or social groups potentially differentiated from each other. With this, as you can see, the budget of understanding falters when defining the communicative phenomenon. It is enough to think about the different forms and contents that the meanings acquire at individual and / or group level from the scenarios of meaning production from which they are constructed and a clear example of what has been said will be taken.

Roughly speaking, that is the reason why the communicative expression by itself never creates interaction, but rather it is the space-time convergence between the different expressions that promote the emergence of a communicative interaction. In this interaction, each expression serves as a perceptual threshold of another, so that the expression of one communicator acts as a source for the construction of meanings for the expression of the other. It is this, in essence, that makes it possible to build the social relationship, society itself; since the convergence between subjective expressions via communication puts individuals and social groups in a relationship of sociality. That is why the form and content of this social relationship will depend on the way in which these individuals perceive themselves and others, as delineated by Simmel (2014).

In that sense, it is plausible to think that, as defined here, communicative interactions are not exempt from misunderstandings and misunderstandings, which facilitates the emergence of conflicts that are nothing more than the 
reflection of the subjective state resulting from the way in which meanings that function as individual and / or socio-cultural references for individuals and / or social groups are constructed. These are deployed based on the forms and contents acquired by the social relations between the communicators at a given time. Let's see how all this can be illustrated through the emerging citizen political expressions that we deal with in this text.

The emerging citizen political expressions in contemporary times acquire meaning and visibility in the face of the silence or inefficiency of government authorities to solve social problems, on the one hand; but on the other, it is the air of democratization and demand for rights, which also configure a contextual atmosphere that makes it possible to explain the emergence of these new types of citizen practices. In our view, both factors combine to form a breeding ground conducive to the emergence of a collective experience that is developed and configured from these coordinates, resulting in turn the emergence of meanings related to the claim of diversity through the vindication of cultural differences, which is where these emerging citizen political expressions are promoted in inclusive terms. From this perspective, a position such as the one advocated by Wolton (1998: 10) about political communication as the space in which they exchange, via the media, the speeches or expressions of legitimate political actors (who are politicians, journalists and public opinion), is insufficient to understand the phenomena of emerging citizen political expression to which we have been referring. The need to rethink a concept of political communication that includes the political, even beyond the individual / civil society-State relationship, is evident.

In this sense, recent work on social networks and elections can be traced, for example, Meeks, L. (2016), particularly Tweeted, deleted: theoretical, methodological, and ethical considerations for examining politicians 'deleted tweet. This paper shows an analysis of the construction and management of the social networks of the candidates in the elections, specifically focusing on the contents that are eliminated by them and the meanings or strategies that these deleted messages acquire in the context of the elections. This proposal is anchored in the exchange of relationships that occur in social networks. It is a study that shows a part of the contemporary problem of how political trajectories are being built in the media by those who participate as direct actors in politics. It is undoubtedly an antecedent to understand current strategies for the construction of politics within the framework of interactions. Other work of this same court can be located in, as in Aligning and trespassing: Candidates' party-based issue and trait ownership on Twitter Meeks, L. (2016) These works are helpful to think about the perspective of communicative phenomenon as an expression although here We try to think about the integration between politics and politics, not only as a media expression but also as an expression among the subjects in their different fields of action.

Following Mier (2000: 70), as the difference between the terms "political" and "political" lies in the institutionality of the first and the spontaneity of the second, it is necessary to rethink the forms and contents that underlie that spontaneity, which expresses a correlation with the conditions of origin of the emerging citizen political expression at the very root of its emergence, that is, from the historical experience of the socio-historically situated citizen subject. Given this framework, there are empirical approaches that account for the integration between politics and politics. This is illustrated by the work of Reedy, J. (2015). Paths to the practices of citizenship: Political discussion and socialization among Mexican-heritage immigrants in the US. This paper deals with the model of social contact and the socialization of politics in the case of immigrants in the United States. This prespective above all accounts for the behavior and learning of certain groups in the political discussion. Another empirical work from this perspective from the microinteractions we can register is that of Johnson, A. J., Bostwick, E. N., \& Cionea, I. A. (2019). Talking Turkey: Effects of Family Discussions About the 2016 Election over the Thanksgiving Holiday. This proposal delineates a more intimate perspective of how family discussions regarding the vote are socialized. Particularly in the 2016 elections in the United States. It shows the practical consequences of how it is and how political socialization processes are managed from the family environment. In this sense, they are more linked to the proposal that we present here, since it includes the process of how in private areas, meanings emerge that, from their different modes of articulation, converge and form part of public issues. However, in this proposal we try to formulate the problem as an expressive phenomenon that does not necessarily occur only in the field of interactions but also from the most unique expressions such as individual ones. We believe that in this way we can give a more adequate account of the articulation between the political and the political in contemporary times.

To the extent that the political expresses the singularity of the impulse of collective action that is part of the public confrontation between social subjects (Mier, 2000: 61), the political constitutes a movement, a spectrum of forms, resources, strategies, dynamics and aftermath of the exercise of power and its limits, which breaks into the social space for some reason and becomes a collective event, "appearing", "happening", in the social fabric without saturating or depleting the social action itself (Mier, 2000: 73).

Understanding the above implies understanding the emerging citizen political expression as an event that, although it may be precarious, to the extent that the conditions that originate it persist, or that it is installed - as we maintain here - as part of a democratic lifestyle - It can also be an event articulated in the time of durability and unpredictable consequences not only of socio-political order, but as noted by Dagnino (2008) and Kabeer (2005) especially of socio-cultural, symbolic order. 
The demand for citizen rights from the perspective of inclusive citizenship makes it possible to predict the emergence of this democratic, inclusive and equitable lifestyle that although seeks to erase, or try to dilute from the guarantee paradigm, the boundaries of all difference and exclusion social, it does nothing but obey - through the emergence of its action / expression - the ideological, social, political and even economic and cultural condition of our current times, whose political-democratic imprint seems to be in crisis today to the constant questioning of democracy in the field of politics.

In that sense, a communicative analysis of the emerging citizen political expression in contemporary circumstances, would necessarily have to be crossed by an analysis, first, of the socio-historical conditions that make its emergence possible in terms of meaning construction, in the manner of an interpretation of the vital sociopolitical environment of existence; Second, an analysis of the communicative resources (in terms of support or projection vehicle of one or more meanings) with which an individual and / or social group has to project them, in this case the citizenship - be it in terms of either individual or collective - from their practices and / or actions, including discursive ones; and finally, it is also necessary an analysis of the motivations and interests from which the same citizens manage to build and project them. To the extent that these expressions are linked or converged with others, we should also analyze, and even determine, the way in which the interaction takes place, repeating the previous analytical process for all the expressions involved.

All that has been said, in some way, ponders the existence of forms and contents in the social relationship through the forms and contents in the emerging citizen political expression in question, since said expression cannot be more than the product or result of what It is lived, felt and thought in a certain way, which impacts the way in which all individual and / or social subjects project and interact with each other, including, of course, the citizen relationship. In the case of the emerging citizen political expression, these forms and contents acquire a peculiarity that we have already been briefly reporting throughout this work, but in the section that follows we will explain them in more detail. Let's see.

\section{The Contemporary Citizen Political Expression: New Forms, New Content}

From the concept of communicative interaction that we have outlined above, the emerging citizen political expression constitutes an expression of the individuals and / or social groups that are projected, communicatively speaking, in the field of politics, that is, in the field of citizen struggle (of citizens) for the recognition of their rights. This implies thinking about the emerging citizen political expression from the subjective, intersubjective and socio-cultural conditions of all kinds (hegemonic and alternative) in which it takes place; hence the importance of taking into account the forms and contents that said expression acquires from the forms and contents with which the social interaction that individuals and / or social groups sustain each other is built, taking into account the approach of the inclusive citizenship from where we propose to think and conceptualize these phenomena. The aforementioned presumes the existence of a type of social relationship that has managed to make itself visible homogeneously, that is, as a collective, despite the possible disagreements and conflicts of interest that are managed from it. In that sense, in order to analyze this type of social relationship analytically, it is necessary to resort to a micro-sociological approach that articulates this social relationship from phenomenological positions, as a result of the convergence of the expressions that circulate under its protection, conforming it. This micro-sociological approach seems to be optimally summarized in Simmelian, centered sociology - as Nisbet points out (quoted in Ritzer, 1997: 300) - in social interaction from both the sociological and psychological point of view, and we would add, phenomenological as well. Simmel's relational sociology seeks to explain the existence and functioning of society as a broad set of social relationships where both institutionalized relationships and many times also marked by power, such as those from where solidarity relations take place, co-participation and collaboration.

For Simmel (2014), there are five basic levels of analysis of social relationships: the psychological level of social life in individuals; the level of the forms of socialization among these; the level of social relations themselves; the level of the formation of interactive forces that are perceived as independent and representative of a collective; and finally, the level of the principles and ideals that govern the future (Ritzer, 1997: 302). All these levels, according to Simmel, are closely linked, so there is no one more important than another, thus creating, in its own interrelation, the structure of a society.

In this way, social relations are for the Berlin sociologist reciprocal actions that enable the emergence of society (Simmel, 2014: 132), so that in its terms there is society when several individuals enter into reciprocal action based on certain instincts (sensual interests, he calls them) and ends (ideal interests), in such a way that such action not only creates relationships of coexistence or conflict, but just from them a mutual influence between individuals is generated (Simmel, 2014: 102- 103). This, however, does not mean discarding the action of third parties and therefore the changes that this can generate inside.

Thus understood, in Simmel's terms, any social relationship can be determined from the interrelation between form and content. The form, according to Ritzer (1997: 308) are models of thought or meaning, while the way in which the relationship or reciprocal action is given is revealed through them. Content, on the other hand, is an event; an event that is marked by the need, the impulse, interest or motivation from which this form is carried out (Simmel, 2014: 103). This, as you can see, makes the form structure the content that, in essence, is diffuse and disorganized (Ritzer, 1997: 309). For that 
reason, Levine (2002: 6) points out that the content in Simmel is an aspect of existence that determines itself, while the form is the synthesis of experience.

From this perspective, as you can see, the relationship between form and content is not only necessary, but immanent to the social relationship itself since the forms, being considered as dynamic and changing cognitive categories that shape the content, fracture the undifferentiated unit which constitutes the immediate experience of the event (Levine: 6) to finally constitute an identity structure with its own meaning that tends to objectify itself as a form; while the content, as subjective and dependent on the different individuals, is transformed and adapted to the form in question. It is, as you can see, a tensional structure, although never paradoxical, which is where Simmel creates all social relations. But it is also in this tension of the social relationship where the instance of needs and / or purposes that make some individuals relate to others, each one - as Simmel (2014) points out - from their own psychological and logical trenches, and from the interrelations or interlaced historical or conjunctural events that occur in everyday life. This way of seeing and studying society, as we have said before, invites us to focus attention on the conditions that make socialization possible, no longer from the configurations inscribed in the social structure itself - and of course without ignoring them - but rather, from the individual psychology and logic of each individual, from their own individual interests, to the most combined with those of other individuals with the same or similar needs and interests. In that sense, the challenge posed by the simmeliana conceptualization of social relationship to understand the emerging citizen political expression, is precisely to realize how the bond between individuals is formed, from the perspective of inclusive citizenship, as stated from the citizen-citizen bond.

Under these premises, one must then think about the impossibility of agreeing a total convergence between interests and motivations of the multiple individuals and / or social groups that make up one or more emerging citizen political expressions today. In this way, these political expressions - whether they occur in purely discursive or practical terms, in the order of social or collective action - will always be marked by the guarantee paradigm of diversity and the claim of difference; that is to say, they will always be marked by making clear the right to individuality and from there the right to inclusion, to recognition.

From the postulates of Simmelian sociology, this right to individuality is explained from the criterion of individual particularity to which Simmel alludes to explain the dissimilar forms and contents acquired by the five types of social relationship that we will shortly characterize. And it is that individual particularity, as intrinsically related to the idea of the logical and psychological trenches of individuals that are linked in a social relationship, prevents one individual from being able to fully represent the other (Simmel, 2014: 124), since he always establishes with him a kind of reference relationship from himself that prevents his perfect or complete knowledge. From this perspective, the social relationship continually bears the imprint of a "social veil" (Simmel, 2014: 126), which makes the reality of the other always "veiled" (mediated, would be a better term) by the generalization we make from him via individual representation.

This kind of insociality that prevents, or at least hinders, the complete knowledge of the other, and in this case that of the other citizen as well, creates an incomplete social relationship that causes individuals to interact from certain psychological and logical positions, and not from others. This, as you can see, fits perfectly with the concept of communication as an expression that has been briefly developed here in the previous section, and also pays for the concept of communicative interaction as a convergence between subjective expressions that have also been defended here; Hence, when Simmel refers to the double situation of the individual in socialization (that of being understood in its interior through the gestated social relationship, and that of simultaneously being able to stand in front of it), this implies not only the characterization of the unitary position of the individual as a social and personal being that can be realized from the personal as a social being and vice versa, but also the idea that this double situation of the individual in socialization explains it, communicatively and politically, as a citizen in all his autonomy and responsibility.

From the perspective of inclusive citizenship, the social relationship between citizens in favor of a democratic lifestyle that advocates the claim of difference and diversity, it is assumed that this social relationship does not occur in the form of subordination and conflict, but rather in the form of a coexistence and realization of the duality of being in the social relationship that, as Dagnino said (2008) favors the emergence of a more inclusive society.

There are five types of social relationships that Simmel himself outlines in terms of the absence or presence of control and regulation mechanisms between individuals and social groups, namely: of sociability (which creates relationships of horizontality, harmony and enjoyment), of conflict (where social relations are forged from a problem or tension), of exchange (any form of social relationship where there is mutual benefit), of subordination (where one individual submits to another due to their weakness or disability) and supra-ordination (where subordination is implied by compliance with certain institutional rules). From this it seems clear that when an individual from his personal being manages to perform in his social being and vice versa - as is possible to anticipate that it occurs in collective action, or in the simple recognition of the other as a subject of law -, it is The social relationship must not be signed or crossed by power. The configuration of a different social relationship, more horizontal and organic, based on affective and coincidental interests, are precisely 
those that manage to articulate this ideal of double realization, beyond the influence that social structures can exert; and that is the social relationship that is established from the emerging citizen political expression in our day, although we must clarify that the term emergent designates a reality not yet widespread. This type of more inclusive and horizontal social relationship, Simmel (2014) names it as a sociability relationship and is what we believe occurs in the emerging citizen political practices that we have described before, which, according to the author, generally take place through a social interaction that is defined from the individual-individual relationship, without detracting from its existence in others such as those of institutionalized structure (individual-institution: the family, the union, party, etc.), the autonomous recreational (form -form: art, sport, games) and that of society (set of social forms).

In the case of emerging citizen political expressions, where individual-individual social forms dominate, it is quite suggestive to think of the way in which these individuals interrelate horizontally and based on the full recognition of the other, even virtually, around an objective or common interest: the citizen's recognition of the other as a subject of law. From this perspective, the form of this type of social relationship would basically be that of sociability, activating from the point of view of the concept of Simmelian content an event that seeks the recognition of subjects as subjects of law and their performance in that sense as citizens. Undoubtedly, this invoices the emergence of a community of interests that without making it fully aware, in turn allows the emergence of citizen activism even from the individual level, as unified in the heat of the struggle for the recognition of rights against exclusion and in favor of difference in its broadest sense, which is what potentially gives them a certain identity as a collective.

The formation of this emerging citizenship undoubtedly accelerates the return to the origin of democratic principles of equality and freedom, accusing a sense of citizenship that - through this claim around subjective recognition - expresses, communicates, says, its political participation to through a conception of a democratic lifestyle that empowers citizens from the civilizational imperative of the ideal of a more inclusive, more equitable, more just society.

Thus, this form of socialization (sociability) promotes more equitable social relationships between individuals and / or social groups, through which it is possible to install a kind of collective representation that socially and potentially articulates the ideals and social values of democracy as ideal Through the approach of inclusive citizenship, this meeting / articulation between these values from the paradigm of expanded rights would echo the principles of civility that should govern democracy, both in its variant of form of government (politics) and in his lifestyle variant (the political). In that sense we can affirm that the emerging citizen political expression stands as the communicative instance from which democracy is combined in the resolution of the divergence between equality and freedom, through the rights paradigm.

\section{Conclusions}

As it has been observed, in this text we have managed to gather three apparently different disciplinary perspectives: science and political philosophy (from the citizen's approach to rights), communication (from the approach of expression) and sociology (from the sociability approach). This has allowed the approach, necessarily interdisciplinary, of the emerging phenomena linked to the political action of individuals and / or social groups from non-institutional channels where the formation of a new type of citizenship prevails, supported by legitimate claims about recognition of individuals as subjects of rights and within a properly citizen political action, not necessarily collective or oriented to the State.

This constitutes a contribution to the study of these phenomena, which is embodied in a theoretical model from the analytical perspective of communication which enables a phenomenological, historical and critical view of them and through which their emergency is understood from a systemic vision. which articulates the level of empirical reality with the level of cultural rationality that begins to govern with increasing force the evolution of social relations in contemporary times. The ideological position outlined here, therefore, bears the imprint of the urgent need for the re-foundation of Modernity and with it the paradigm of democracy on which it has been built; a democracy that through this emerging citizen action seems to be able to dilute the persistent conflict that crosses it from its own birth: the apparently irreconcilable relations between freedom and equality, under the protection of a civilizing ethos from which one seeks and It proposes a less unequal society, from which, from the recognition to be different, the way is opened for the construction of more symmetrical social relations.

That is why we consider that the emerging citizen political expression in our contemporary societies -while setting up a communication that makes politics- forges the basis for the construction of a truly more democratic democracy. However, in order to make this democracy more democratic a generalized reality, the emergence of ethical imperatives that are necessarily established, as Bárcenas (1997) points out, is necessary in a system of ends, values and ideals inserted in an ethical-political framework. from which the effective approach to this practically ideal democracy is possible from the improvement and strengthening of these values, ends and ideals. To this, no doubt, the paradigms of rights contribute from the multiculturalist approach and that of inclusive citizenship; and hence, also, the viability and relevance of the dissimilar emerging citizen political expressions that, under the protection of these values, ideals and ends, demand a more just society by way of the requirement of the recognition of all individuals in their difference as subjects of rights. 


\section{References}

Arendt, H. (1997). ¿Qué es la política?. Barcelona: Paidós.

Bárcenas, F. (1997). El oficio de la ciudadanía. Introducción a la educación política. Barcelona: Paidós.

Blanco, A. D. D. (2005). El bienestar social: su concepto y medición, Psicothema, 17(4), 582-589.

Dagnino, E. (2008). Los significados de ciudadanía en América Latina. en Chaparro, Adolfo, Carolina Galindo y Ana María Sallenave (eds.) Estado, Demoracia y populismo en América Latina. Bogotá: Editorial Universidad del Rosario, 194-227.

Díaz, Á. (2003). Una discreta diferenciación entre la política y lo político y su incidencia sobre la educación en cuanto a la socialización política. Reflexión Política, 5(9), 49-58. Colombia: Universidad Autónoma de Bucaramanga.

Díaz, Á. G. V. (1998). "Educación y democracia" en Cardona, Silvio et al Educación y democracia. Lecturas desde la Universidad Católica de Manizales. Manizales: Centro Editorial Universidad Católica.

Johnson, A., Eryn, B., \& Ioana, C. (2019). Talking Turkey: Effects of Family Discussions About the 2016 Election over the Thanksgiving Holiday. Journal of Family Communication, 19(1), 63-76. https://doi.org/10.1080/15267431.2018.1543688

Kabeer, N. (2005). En busca de una ciudadanía incluyente: sus significados y expresiones en un mundo interconectado. en Kabeer, Naila Ciudadanía incluyente significados y expresiones. México: UNAM-PUEG, 7-36.

Kymlicka, W. (1996). Ciudadanía multicultural. Barcelona: Paidós.

Levine, D. (2002). Georg Simmel: Individuality and Social Forms. Chicago: University of Chicago Press.

Marshall, T. (1998). Ciudadanía y clase social. Madrid: Alianza. https://doi.org/10.2307/40184017

Meeks, L. (2016a). Tweeted, deleted: theoretical, methodological, and ethical considerations for examining politicians' deleted tweets. Information, Communication \& Society. Online advance publication.

Meeks, L. (2016b). Aligning and trespassing: Candidates' party-based issue and trait ownership on Twitter. Journalism \& Mass Communication Quarterly, 93(4), 1050-1072. https://doi.org/10.1177/1077699015609284

Meirick, P., \& Elena, B. (2015). Epistemic factors in selective exposure and political misperceptions on the right and left. Analyses of Social Issues and Public Policy. Published online, November 25. https://doi.org/10.1080/10646175.2014.986312

Meirick, P., \& Stephanie, S. D. (2015). Obama as exemplar: Debate exposure and implicit and explicit affect toward African-Americans. Howard Journal of Communications, 26(1), 57-73.

Mier, R. (2000). Apuntes para una reflexión sobre comunicación y política. Versión, (10), 59-105.

Mouffe, C. (1999). El retorno de lo politico, Barcelona: Paidós.

Olvera, A. (2008). Ciudadanía y Democracia, México: IFE.

Peters, J. (2014). Hablar al aire. Una historia sobre la idea de la comunicación. México: CFE. https://doi.org/10.1080/17475759.2015.1053823

Reedy, J. (2015). Paths to the practices of citizenship: Political discussion and socialization among Mexican-heritage immigrants in the US. Journal of Intercultural Communication Research, 44, 201-223.

Reedy, J., Gastil, J., \& Moy, P. (2015). From the secret ballot to the public vote: Examining political discussion in vote-by-mail elections. Political Communication, 33, 39-58. https://doi.org/10.1080/10584609.2014.969462

Reguillo, R. (2003). Ciudadanías juveniles en América Latina. Última Década, 19, CIDPA, Viña del Mar, 11-30. https://doi.org/10.4067/S0718-22362003000200002

Ritzer, G. (1997). “Georg Simmel” en Teoría sociológica clásica. México: Mc Graw Hill, 299-331.

Romeu, V. (2016). Pensando la comunicación y el fenómeno comunicativo. en XXXI Anuario CONEICC, 17-55.

Romeu, V. (2018). El fenómeno comunicativo. México: Editora Nómada.

Simmel, G. (2014). Sociología: Estudios sobre las formas de socialización. México: FCE.

\section{Copyrights}

Copyright for this article is retained by the author(s), with first publication rights granted to the journal.

This is an open-access article distributed under the terms and conditions of the Creative Commons Attribution license which permits unrestricted use, distribution, and reproduction in any medium, provided the original work is properly cited. 